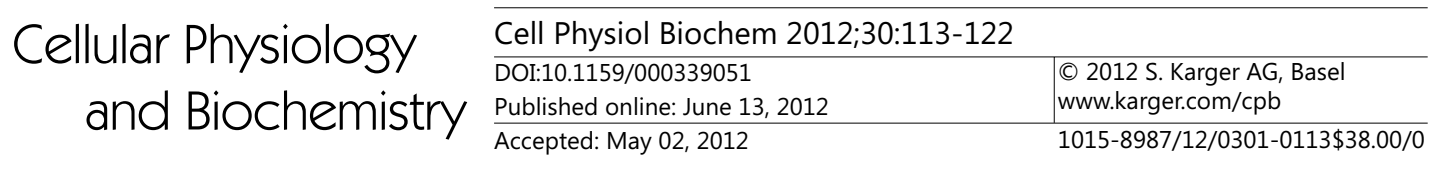

\title{
Human Periprostatic Adipose Tissue: its Influence on Prostate Cancer Cells
}

\author{
Paula Alejandra Sacca ${ }^{1}$ Virginia Pistone Creydt ${ }^{1}$ Hosoon Choi ${ }^{2}$ Osvaldo Néstor \\ Mazza $^{3}$ Sabrina Johanna Fletcher ${ }^{1}$ Valeria Beatriz Fernández Vallone ${ }^{1}$ Carlos \\ Scorticati $^{3}$ Norma Alejandra Chasseing ${ }^{1}$ Juan Carlos Calvo ${ }^{1,4}$ \\ ${ }^{1}$ Instituto de Biología y Medicina Experimental (IBYME) - CONICET - Buenos Aires; ${ }^{2}$ Institute for \\ Regenerative Medicine, Texas A \& M Health Science Center, Temple, Texas; ${ }^{3}$ Hospital de Clínicas \\ "José de San Martín" - Cátedra de Urología - Facultad de Medicina - Universidad de Buenos Aires; \\ ${ }^{4}$ Departamento de Química Biológica, Facultad de Ciencias Exactas y Naturales, Universidad de Buenos \\ Aires - Ciudad Universitaria - Buenos Aires
}

\section{Key Words}

Periprostatic adipose tissue - Periprostatic fat - Adipose tissue - Metalloproteinases • Microenvironment $\bullet$ Prostate cancer

\begin{abstract}
Background/Aims: Adipose microenvironment is involved in signaling pathways that influence prostate cancer ( $\mathrm{PCa}$ ) progression. However, the role of human periprostatic adipose tissue (PPAT) from patients with benign prostatic hyperplasia (BPH) has not been studied and compared to that of PPAT from PCa patients. The aim of this paper was to investigate the influence of factors derived from both PPATs on the behavior of androgen-dependent and castration resistant PCa cells. Methods: PPAT conditioned media (CM) were obtained from tissue samples from patients with clinically primary PCa (TPPAT) or BPH (BPPAT). Cell adhesion, proliferation, migration and metalloproteinase expression were evaluated following exposure of LNCaP (androgen dependent) and PC3 (androgen independent) prostate cancer cell lines to BPPAT or TPPAT CM. Results: Proliferation or motility of $\mathrm{LNCaP}$ or PC3 cells were not significantly affected by TPPAT or BPPAT CM. The number of $L N C a P$ but not PC3 cells attached to components of TPPAT CM significantly decreased compared to cells attached to BPPAT CM. PPAT produced and released pro-MMP-9. Zymograms demonstrated that TPPAT CM induced a significant increase in pro-MMP-9 activity compared to BPPAT CM in LNCaP cells but not in PC3 cells. Conclusions: We conclude that TPPAT released factors, such as pro-MMP-9, could induce the invasive capacity of LNCaP cells and speculate that PPAT derived factors could, in the early stages of prostate cancer, modulate disease progression.
\end{abstract}

Copyright $@ 2012$ S. Karger AG, Basel 


\begin{tabular}{|c|c|c|}
\hline $\mathrm{Col}$ & Cell Physiol Biochem 2012;30:113-122 & \\
\hline and Biochemistry & $\begin{array}{l}\text { DOI:10.1159/000339051 } \\
\text { Published online: June 13, } 2012\end{array}$ & $\begin{array}{l}\text { O } 2012 \text { S. Karger AG, Basel } \\
\text { www.karger.com/cpb }\end{array}$ \\
\hline
\end{tabular}

\section{Introduction}

Adipose tissue (AT) is present in the periphery of the prostate $[1,2]$ and patients with higher periprostatic fat density have been often shown to have a more aggressive prostate cancer [3]. Moreover, increased PPAT thickness has been recently associated not only with prostate cancer but also with a high-grade prostate cancer diagnosis [4]. AT is involved in the storage and release of energy and in the regulation of energy metabolism via secretion of a variety of adipokines [5] which modulate the biology of prostate cancer (PCa) cells $[6,7]$.

Molecular studies on periprostatic adipose tissue (PPAT) are few and very recent. Finley et al. [8] screened cytokines and growth factors, such as IL-6, in conditioned medium of PPAT from PCa patients; Ribeiro et al. [9] determined that PCa cell derived factors influence PPAT metabolic activity in patients with PCa. However, up to date, no study has compared the role of PPAT in patients with benign prostatic hyperplasia (BPH) and PCa patients.

Tumor metastasis involves interactions between invasive cells and host stromal components [10] which promote degradation of extracellular matrix (ECM) by proteolytic enzymes from both cell types. Stromal-epithelial crosstalk is integral to PCa progression and metastasis, as well as androgen signaling at both the primary and metastatic sites [11]. Metalloproteinases (MMPs) are a family of endopeptidases whose catalytic function is degradation of the protein components in the ECM in the microenvironment immediate to tumor cells [12]. They can process growth factors, cytokines, chemokines, cell receptors, serine protease inhibitors and other MMPs affecting tissue homeostasis [13]. The localization, activation and activity of MMPs are regulated by interactions with other proteins, proteoglycans and/or their glycosaminoglycan chains [14]. MMPs are overexpressed in cancer tissues suggesting an important role in tumor invasion.

In this paper, we investigated the effect of conditioned media (CM) from human PPAT, isolated from PCa patients (TPPAT) and patients with BPH (BPPAT) on proliferation, MMPs activity, migration and adhesion of two epithelial PCa cell lines: LNCaP and PC3. LNCAP are less aggressive and androgen-sensitive and thus represent the first stages of the disease, and PC3, more aggressive and androgen-insensitive, constitute a model for its final stages [15-20].

\section{Materials and Methods}

Cell culture and reagents

LNCaP and PC3 cells were obtained from the American Type Culture Collection (Manassas, VA, USA) and maintained in RPMI 1640 medium supplemented with $10 \%$ fetal bovine serum (FBS) and antibiotics. Chemicals and reagents were purchased from Sigma (St. Louis, MO, USA) unless otherwise stated; tissue, cell culture media and supplements from Gibco BRL (Carlsbad, CA, USA).

Ethic Statement and tissue procurement

Human PPAT was obtained from 8 patients undergoing radical prostatectomy for localized prostate tumors (TPPAT, age range 57-69 years, mean 61.9 years) and 6 patients undergoing adenomectomy for BPH (BPPAT, age range 63-79 years, mean 70 years). None of the patients had received preoperative therapy. All patients gave their written consent to undergo tissue harvesting for this research and IBYME ethics committee approved the procedures.

In every case, once the anterior surface of the prostate had been surgically exposed, the fat tissue surrounding the superficial venous plexus of Santorini was dissected. A fatty, loose tissue surrounds this plexus on both sides of the inferior portion of the anterior surface of the prostate and approximately $0.5-2$ $\mathrm{g}$ of this fat tissue was separated for further processing.

Clinical and pathological characteristics of the specimens used (age, Gleason score and pTNM) are shown in Table 1. All BPH specimens showed histological epithelial and/or stromal cell hyperplasia but no malignant cells. to a Petri dish and extensively washed with $50 \mathrm{ml}$ ice-cold phosphate buffer saline solution (PBS) 


\begin{tabular}{rl|l} 
Cellular Physiology & $\begin{array}{l}\text { Cell Physiol Biochem 2012;30:113-122 } \\
\text { and Biochemistry }\end{array}$ & $\begin{array}{l}\text { DOI:10.1159/000339051 } 2012 \text { S. Karger AG, Basel } \\
\text { Published online: June 13, 2012 }\end{array}$ \\
\cline { 2 - 3 } Sacca/Creydt/Choi et al.: Periprostatic Adipose Tissue and Prostate Cancer
\end{tabular}

Table 1. Clinicopathological characteristics of prostate cancer patients

\begin{tabular}{cccc}
\hline $\begin{array}{c}\text { Patient } \\
\text { code }\end{array}$ & Age & Grade & pStage \\
\hline AT2 & 69 & $3+3$ & pT2bNOM0 \\
AT3 & 66 & $3+4$ & pT2cNOM0 \\
AT4 & 58 & $3+3$ & pT2cNOM0 \\
AT6 & 60 & $4+5$ & pT3bNOM0 \\
AT7 & 64 & $3+3$ & pT3aNOM0 \\
AT8 & 62 & $3+3$ & pT2aNOM0 \\
AT18 & 57 & $4+3$ & pT3aNOM0 \\
AT20 & 59 & $3+3$ & pT3aNOM0 \\
\hline
\end{tabular}

supplemented with gentamicin $(50 \mu \mathrm{g} / \mathrm{ml})$. Washed tissue was transferred to a centrifuge tube containing $35 \mathrm{ml}$ PBS at $37{ }^{\circ} \mathrm{C}$, shaken and centrifuged at $277 \mathrm{xg}$ at RT to remove red blood cells. Tissue was then weighed and placed in a culture flask with M199 culture medium (1g tissue/10 ml M199) supplemented with gentamicin $(50 \mu \mathrm{g} / \mathrm{ml})$ and incubated for $1 \mathrm{~h}$ at $37^{\circ} \mathrm{C}$ in $5 \% \mathrm{CO}_{2}$. Medium was replaced with fresh medium, incubated for $24 \mathrm{~h}$ and the resulting conditioned medium ( $\mathrm{CM}$ ) collected, centrifuged, filtered, aliquoted and stored at $-80^{\circ} \mathrm{C}[5]$.

Conditioned media from prostate cancer cells following incubation with conditioned medium of periprostatic adipose tissue (TPPAT and BPPAT)

LNCaP and PC3 cells were seeded on a 6-well plate. When cells reached 75-80\% confluence, medium was removed; cells washed with PBS, and incubated for $36 \mathrm{~h}$ at $37{ }^{\circ} \mathrm{C}$ with or without TPPAT and BPPAT conditioned media. Resultant CM derived from LNCaP cells (LNCaP-TPPAT and LNCaP-BPPAT) and PC3 cells (PC3-TPPAT and PC3-BPPAT) were clarified by centrifugation at $4{ }^{\circ} \mathrm{C}$ and kept at $-80{ }^{\circ} \mathrm{C}$ until use.

\section{Proliferation assay}

LNCaP $\left(8 \times 10^{3}\right.$ cells/well) and PC3 $\left(3 \times 10^{3}\right.$ cells/well) were seeded in medium on 96-well plates and cultured for $24 \mathrm{~h}$. Subsequently, medium was completely removed and replaced by PPAT CM for an additional 24 and $48 \mathrm{~h}$. Control cells were cultured in M199 medium. Cell proliferation was measured by MTS assay, according to the manufacturer recommendations (CellTiter96 Aqueous One Solution Cell Proliferation Asssay, Promega, Madison WI, USA). Experiments were performed with PPAT from different tumor and BPH donors. Results were expressed as percentage of control values.

\section{Zymography}

Gelatin zymography was performed under non-reducing conditions on a $7.5 \%$ polyacrylamide gel copolymerized with gelatin $(1 \mathrm{mg} / \mathrm{ml})$ to analyze TPPAT, BPPAT, LNCaP-TPPAT, LNCaP-BPPAT, PC3-TPPAT, PC3-BPPAT conditioned media. Because there was no direct correlation between zymographic data and proliferation values for each patient, samples for zymography were not adjusted by cell number and a fixed sample volume $(30 \mu \mathrm{l})$ was loaded on the gel. Gels were washed with $2.5 \%(\mathrm{w} / \mathrm{v})$ Triton-X 100, incubated for $22 \mathrm{~h}$ at $37^{\circ} \mathrm{C}$ in activating buffer $(50 \mathrm{mM}$ Tris- $\mathrm{HCl}$ buffer, $\mathrm{pH} 7.5$, containing $200 \mathrm{mM} \mathrm{NaCl}$ and $5 \mathrm{mM}$ $\mathrm{CaCl}_{2}$ ), stained with $0.5 \%(\mathrm{w} / \mathrm{v}$ ) Coomassie Brilliant Blue R-250 and destained with $7 \%(\mathrm{v} / \mathrm{v}$ ) methanol in $5 \%(\mathrm{v} / \mathrm{v})$ acetic acid. Proteolytic activity was visualized as an unstained area against a blue background. The area of the gelatinolytic bands was analyzed by densitometry using ImageJ software (NIH, Bethesda, Maryland) and molecular weight standards (BioRad, CA, USA) were used to estimate their molecular weight. Gels were incubated in 20 mM EDTA to confirm metalloproteinase activity. Basal metalloproteinase activity was determined in medium obtained from LNCaP and PC3 cells cultured in M199. To observe the changes in metalloproteinase activity of tumor epithelial cells specifically induced by PPAT-CM, endogenous metalloproteinase activity from PPAT-CM and basal activity (cells in M199) were subtracted. Results were expressed as densitometric units.

\section{Cell adhesion assay}

Adhesion assays were performed according to Retta et al [21]. Briefly, 96-well plates were coated with $100 \mu \mathrm{l}$ of TPPAT-CM or BPPAT-CM and kept at $37^{\circ} \mathrm{C}$ overnight in $5 \% \mathrm{CO}_{2}$. Control wells were coated with M199 medium. Each CM was set in 3 wells and each experiment was repeated three times. Plates were blocked with $1 \mathrm{mg} / \mathrm{ml}$ bovine serum albumin at $37^{\circ} \mathrm{C}$ for $1 \mathrm{~h}$. After washing the wells with PBS, LNCaP or PC3 cells $\left(5 \times 10^{4}\right.$ cells/well) suspended in serum-free RPMI 1640 medium were seeded and allowed to adhere to the coated wells for $1 \mathrm{~h}$ at $37^{\circ} \mathrm{C}$ in $5 \% \mathrm{CO}_{2}$. Non-adherent cells were aspirated and wells washed with PBS. Cell adhesion to PPAT-CM proteins was determined by the MTS assay according to manufacturer's 


\section{Cellular Physiology \\ Cell Physiol Biochem 2012;30:113-122 \\ and Biochemistry
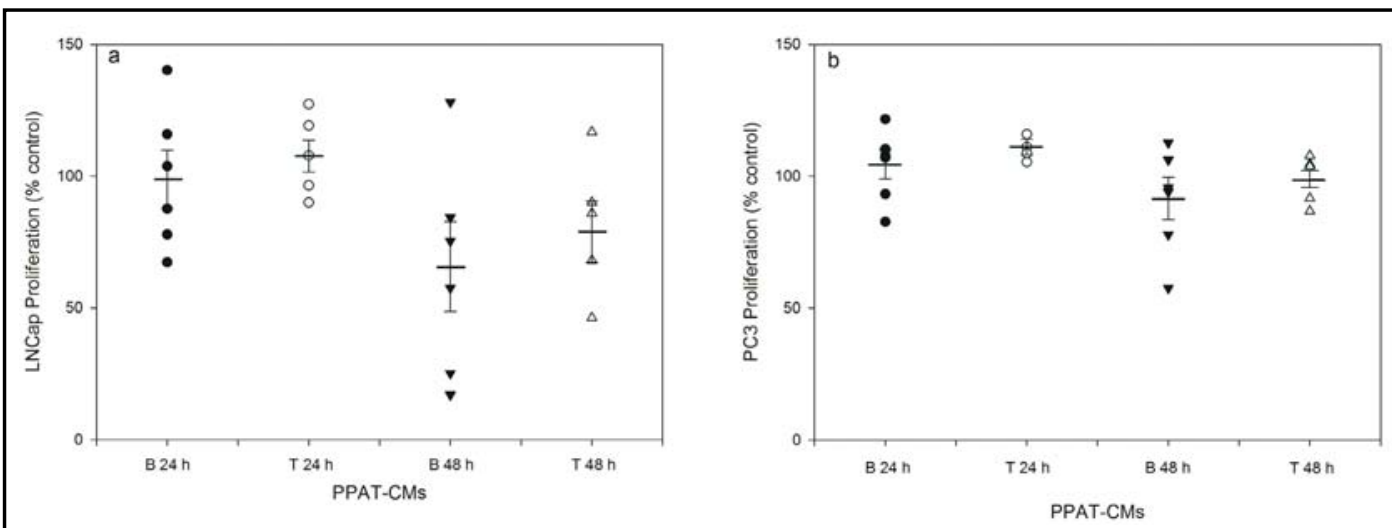

Fig. 1. Effect of CM from TPPAT and BPPAT on proliferation of LNCaP and PC3 cells. (a) LNCaP and (b) PC3 were incubated with BPPAT CM (B) or TPPAT CM (T). Epithelial prostate cancer cells were seeded into 96-well plates and exposed to PPAT CM for 24 and $48 \mathrm{~h}$. Growth was assessed by MTS assay. Each point represents the mean of three independent experiments, performed in triplicate. Proliferation is indicated as percentage of proliferation observed in control medium (M199). Horizontal bars represent the geometric mean of each data set. Vertical bars indicate SEM. No significant differences were observed among groups (Dunn's Multiple Comparison Test).

protocol; results were expressed as percentage of control values. In order to establish the possible involvement of hyaluronic acid and chondroitin sulfate in the adhesion process, PPAT-CM pretreated with 5 $\mu \mathrm{l}$ of Chondroitinase ABC (ChABC) (2 units/ml) (Sigma-Aldrich Chemie, GmbH, Germany) were used [22].

Cell migration (wound-healing) assay

LNCaP or PC3 confluent cell monolayers were wounded with a pipette tip. After washing once with PBS, cells were incubated with BPPAT-CM and TPPAT-CM; M199 medium was used for control wells. Images at $0 \mathrm{~h}$ were captured to record the initial width of the wounds, and the recovery of the wounded monolayers due to cell migration toward the denuded area was evaluated at 6 and $22 \mathrm{~h}$. Images were captured using an inverted phase-contrast microscope (Olympus CKX-41; 4x objective). Quantitative analysis of the wound closure was performed using Image J software and expressed as percentage of control wound (M199) at each time point analyzed.

\section{Statistical Methods}

Statistical analysis was performed using GraphPad Prism software (La Jolla, CA, USA). Specific tests used are described in the corresponding section. Experiments were performed at least 3 times. Data were expressed as mean \pm standard error of the mean.

\section{Results}

Effect of TPPAT and BPPAT CM on proliferation of LNCaP and PC3 cells

Figure 1 illustrates cell proliferation following exposure of PCa cells to PPAT CM. Data showed that some PPATCM induced proliferation of LNCaP cells while other CM inhibited it, regardless of the origin of adipose tissue (patients with cancer or benign prostatichyperplasia). Mean values indicated that neither PPAT CM nor BPAT CM modified proliferation of LNCaP cells at 24 or $48 \mathrm{~h}$ compared to control (Fig. 1a). However, after $48 \mathrm{~h}$ incubation in BPPAT $\mathrm{CM}$ there was a tendency towards a decrease in proliferation, which was less pronounced following incubation with TPPAT CM. On the other hand, when PC3 data were analyzed (Fig. 1b) no modification of cell proliferation with respect to control was observed for either CM at both time points tested. 


\section{Cellular Physiology Cell Physiol Biochem 2012;30:113-122

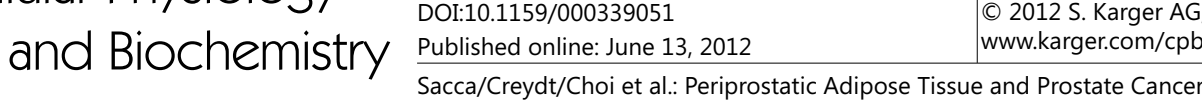

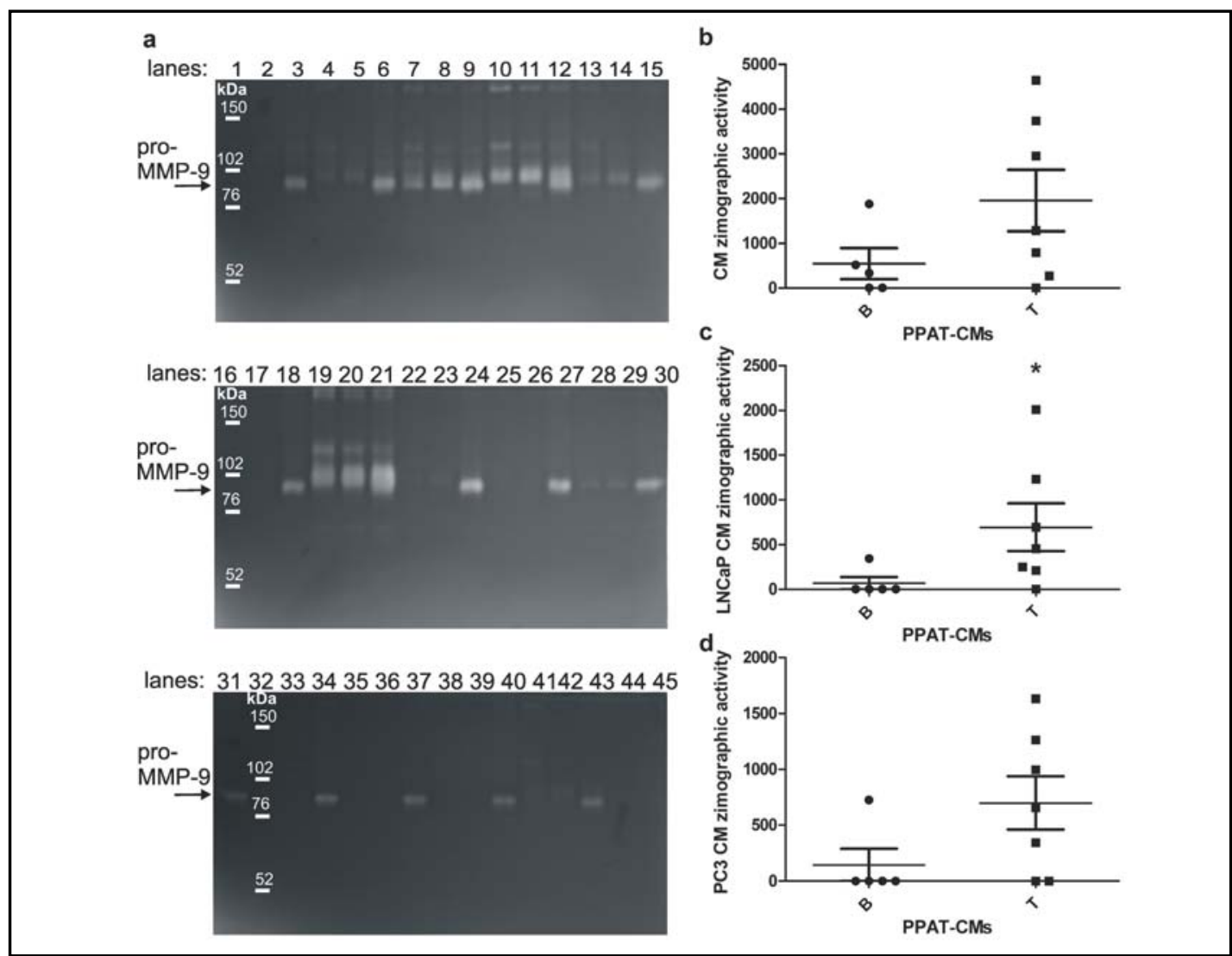

Fig. 2. Effect of CM from TPPAT and BPPAT on metalloproteinase activity in LNCaP and PC3. (a) representative gelatin zymograms of CM of TPPAT (lanes $4,7,10,13,19,22,44$ ), BPPAT (lane 25, 28, 35, 38, 41), LNCaP-TPPAT (lanes 5, 8, 11, 14, 20, 23, 45) and PC3-TPPAT (lanes 6, 9, 12, 15, 21, 24, 31), LNCaP-BPPAT (lanes 26, 29, 36, 39, 42) and PC3-BPPAT (lanes 27, 30, 37, 40, 43). Band molecular weight was estimate by comparison with protein standards. LNCaP (lanes 2, 17 and 33) and PC3 cells (lanes 3, 18 and 34) cultured in M199 medium were included to control for basal activity. (b) to (d) Scattered plots of metalloproteinase activity: CM from BPPAT and TPPAT (b), LNCaP-BPPAT CM and LNCaP-TBPPAT CM (c), PC3-BPPAT CM and PC3-TPPAT CM (d). Each point represents the mean of three independent experiments. Horizontal bars represent the geometric mean of each data set. Vertical bars indicate SEM. A significant difference in proMMP-9 was observed for LNCaP-TPPAT vs LNCaP-BPPAT ( $\mathrm{p}=0.043$, Mann-Whitney Comparison Test).

\section{Effect of CM from TPPAT and BPPAT on metalloproteinase activity of LNCaP and PC3 cells}

Figure 2a depicts the results of representative zymographic analysis of CM from TPPAT (lanes 4, 7, 10, 13, 19, 22, 44), BPPAT (lanes 25, 28, 35, 38, 41), LNCaP-TPPAT (lanes 5, 8, 11, 14, 20, 23, 45), LNCaP-BPPAT (lanes 26, 29, 36, 39, 42), PC3-TPPAT (lanes 6, 9, 12, 15, 21, 24,31 ) and PC3-BPPAT (lanes 27, 30, 37, 40, 43). LNCaP showed no basal activity of proMMP-9 (lanes 2, 17, 33) while PC3 cells did (lanes 3, 18, 34). The bands at about $92 \mathrm{kDa}$ correspond to latent pro-MMP-9 and showed an enlarged area in TPPAT CM (lanes 4, 7, 10, $13,19,22$ ) with respect to BPPAT CM (lanes 25, 28, 41). Gelatinolytic bands of pro-MMP9 were observed in 6 out of 7 (85.7\%) TPPAT CM, and 3 out of 5 BPPAT CM (60\%), with a mean pro-MMP-9 activity (arbitrary densitometric units) of $543 \pm 346$ vs $1951 \pm 687$ for TPPAT and BPPAT, respectively (Fig. 2b). PPAT produces and releases pro-MMP-9, and though PPAT CM from patients with PCa had a tendency to present higher pro-MMP-9 activity than those from patients with $\mathrm{BPH}$, mean values were not statistically different (Fig. $2 \mathrm{~b}$ ).

Pro-MMP-9 activity was detected in 6 out of 7 (87.5\%) LNCaP-TPPAT CM (Fig. 2a, lanes $5,8,11,14,20,23,45)$, and 1 out of 5 (20\%) LNCaP-BPPAT CM (Fig. 2a; lane 42). TPPAT 


\section{Cellular Physiology and Biochemistry

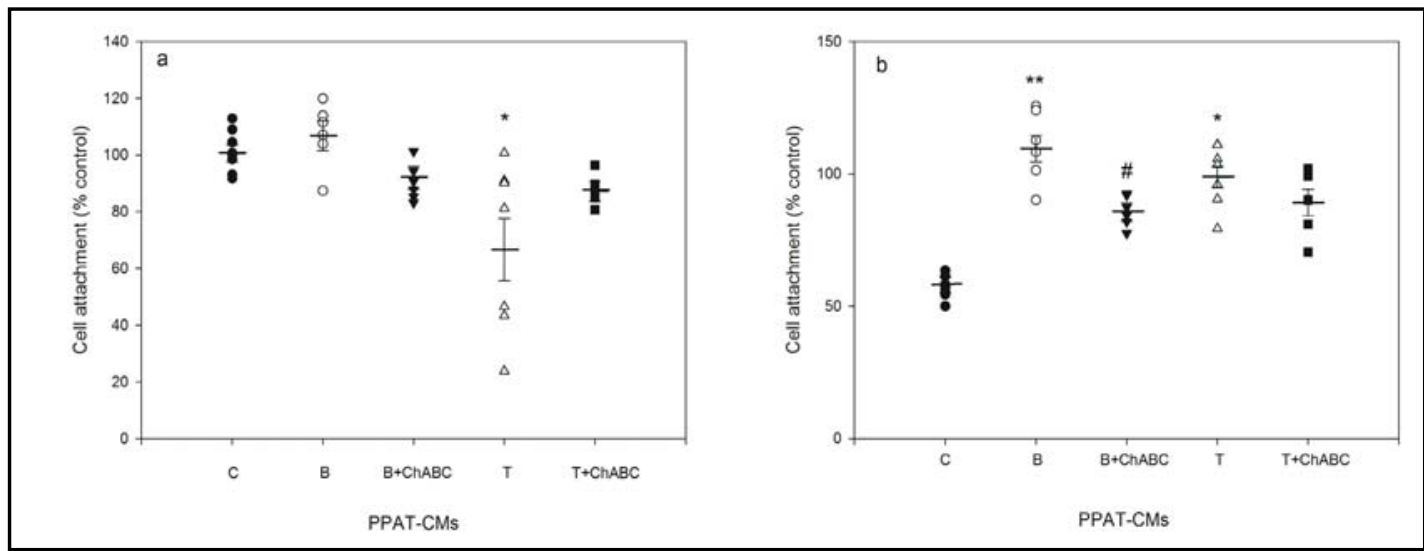

Fig. 3. Effect of CM from TPPAT and BPPAT on LNCaP and PC3 attachment. (a) LNCaP and (b) PC3 were seeded at a density of $5 \times 10^{4}$ cell/well. Each point represents the mean of three independent experiments, performed in triplicate. Horizontal bars represent the geometric mean of each data set. Vertical bars indicate SEM. The number of LNCaP cells attached to components of TPPAT CM was significantly decreased vs BPPAT CM $\left({ }^{*} \mathrm{p}<0.01\right)(\mathrm{a})$. Both BPPAT and TPPAT CM increased cell attachment of PC 3 cells respect to control $\left({ }^{*} \mathrm{p}<\right.$ 0.05 and ${ }^{* *} \mathrm{p}<0.01$, respectively) (b). Pretreatment of BPPAT CM with ChABC decreased cell attachment of PC3 cells $(\# \mathrm{p}<0.05)$ (Dunn's Multiple Comparison Test).

CM induced a significant increase in pro-MMP-9 activity in LNCaP cells compared to BPPAT CM ( $\mathrm{p}=0.0433$, Mann Whitney test) (Fig 2c). On the other hand, pro-MMP-9 activity was detected in 5 out of 7 (71.4\%) PC3-TPPAT CM (Fig. 2a, lanes 6, 12, 15, 21, 24) and only in 1 out of 5 PC3-BPPAT CM (20\%) (Fig. 2a; lane 27). There was a tendency for TPPAT CM to increase pro-MMP-9 activity in PC3 cells compared to BPPAT CM, but mean activities were not statistically different (Fig 2d).

The bands at approximately 100-116 kDa could represent stable complexes of pro-MMP9/TIMP-1 [23], whereas the larger bands ( $>200 \mathrm{kDa}$ ) probably consist of multiple forms of the enzyme [24]. No gelatinolytic bands were detectable when the gels were incubated in the presence of $20 \mathrm{mM}$ EDTA, a typical inhibitor of MMPs (data not shown).

Effect of CM from TPPAT and BPPAT on LNCaP and PC3 cell attachment

TPPAT CM significantly decreased the adherence of LNCaP cells to a surface covered with BPPAT CM $(\mathrm{p}<0.01)$ (Fig. 3a). In contrast, TPPAT CM did not alter the number of attached PC3 cells with respect to BPPAT CM (Fig. 3b). However, both types of PPAT CM increased PC3 cell attachment when compared to adhesion in control medium $(\mathrm{p}<0.05$ and $\mathrm{p}<0.01$ respectively) (Fig. 3b).

To evaluate if PCa cells attachment was mediated by chondroitin sulfate proteoglycans (e.g. versican) and hyaluronan, PPAT CM were pre-treated with the enzyme ChABC, which degrades both chondroitin sulfate and hyaluronic acid. This enzymatic treatment did not modify the effect of TPPAT CM on either LNCaP or PC3 adherence (Fig. 3a and 3b, respectively) but promoted a reduction in PC3 cell attachment in BPPAT CM (p<0.05) (Fig. 3b).

Effect of CM from TPPAT and BPPAT on motility of LNCaP and PC3 cells

Figure 4a and Figure 5a show representative light microscopy images of LNCaP and PC3 wounds respectively. As shown in Figures $4 \mathrm{~b}$ and $5 \mathrm{~b}$, neither TPPAT nor BPPAT CM affected the motility of LNCaP cells at 6 or $22 \mathrm{~h}$ or of PC3 cells at $6 \mathrm{~h}$. There was a slight, though not significant, inhibition in cell motility with respect to control when PC3 cells were incubated with TPPAT or BPPAT CM for $22 \mathrm{~h}$ (Fig. 5b). 


\section{Cellular Physiology $\quad$ Cell Physiol Biochem 2012;30:113-122

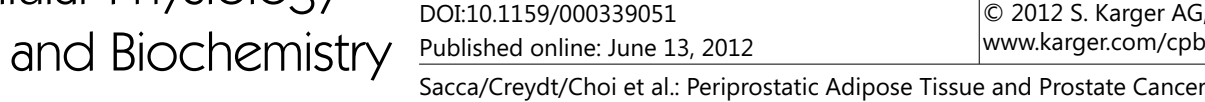

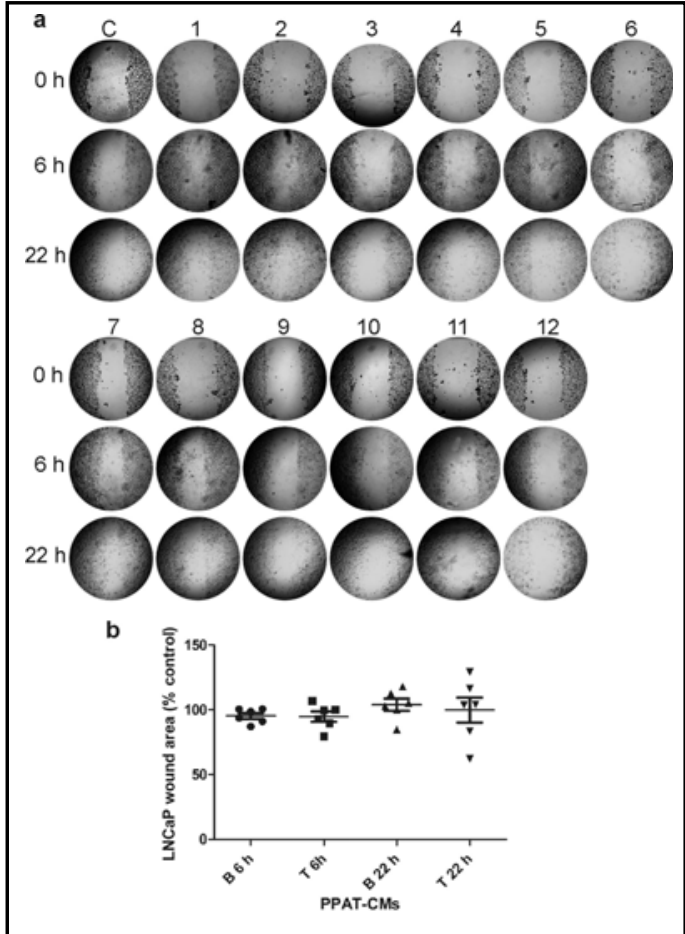

Fig. 4. Effect of CMs from TPPAT and BPPAT on motility of LNCaP cells. (a) Representative light microscopy images $(4 \mathrm{x})$. Cells were grown to confluence, wounded and then incubated with TPPAT $(1-6)$ or BPPAT CM $(7-12)$. Images were captured at 0,6 and $22 \mathrm{~h}$ after wounding. (b) Quantitative analysis of the wound closure was performed using Image J software and expressed as percentage of control wound (M199) at each time point analyzed. Each point represents the mean of three independent experiments, performed in triplicate. Horizontal bars represent the geometric mean of each data set. Vertical bars indicate SEM. Neither BPPAT nor TPPAT CM had any impact on cell motility of LNCaP (Dunn's Multiple Comparison Test).

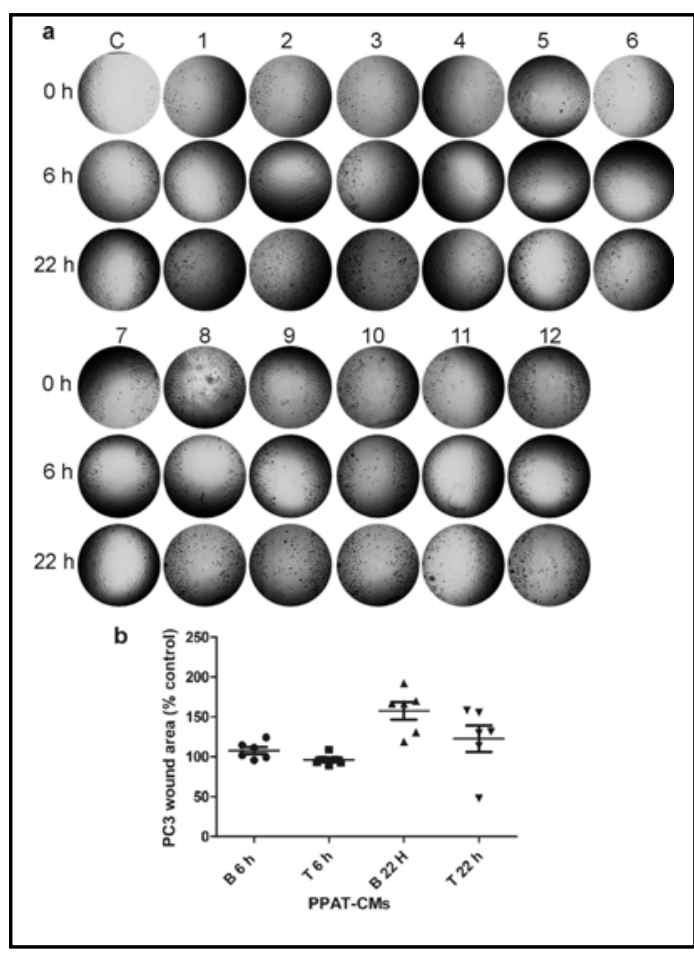

Fig. 5. Effect of CM from TPPAT and BPPAT on motility of PC3 cells. (a) Representative light microscopy images $(4 \mathrm{x})$. Cells were grown to confluence, wounded and then incubated with TPPAT $(1-6)$ or BPPAT CM $(7-12)$. Images were captured at 0 , 6 and $22 \mathrm{~h}$ after wound. (b) Quantitative analysis of the wound closure was performed using Image J software and expressed as percentage of control wound (M199) at each time point analyzed. Each point represents the mean of three independent experiments, performed in triplicate. Horizontal bars represent the geometric mean of each data set. Vertical bars indicate SEM. Neither BPPAT nor TPPAT CM had any impact on cell motility of PC3 (Dunn's Multiple Comparison Test).

\section{Discussion}

In the last few years, scientific literature has suggested that tumor microenvironment has a decisive role in controlling local cancer growth, invasion and distant metastasis [25]. Particularly, PCa microenvironment may be influenced by PPAT and could affect tumorigenesis and possibly even aggressiveness [8]. For example, the regulation of adipokine expression by tumor CM indicates to what extent tumor cells are capable of inducing PPAT to produce factors that could favor their aggressiveness [9].

Although PPAT invasion has been regarded as a factor related to adverse prognosis in patients undergoing radical prostatectomy, the molecular mechanisms mediating the progression of PCa following the invasion of cancer cells into the PPAT remain to be elucidated. 


\section{Cellular Physiology Cell Physiol Biochem 2012;30:113-122 \\ \begin{tabular}{ll|l}
\cline { 3 - 3 } and Biochemistry & $\begin{array}{l}\text { DOI:10.1159/000339051 } \\
\text { Published online: June 13, } 2012\end{array}$ & $\begin{array}{l}\text { C 2012 S. Karger AG, Basel } \\
\text { www.karger.com/cpb }\end{array}$ \\
\cline { 2 - 3 } Sacca/Creydt/Choi et al.: Periprostatic Adipose Tissue and Prostate Cancer
\end{tabular}}

To study to what extent the degree of cell aggressiveness of PCa may be attributed to intrinsic properties of the tumor cells and/or the PPAT microenvironment, we evaluated the effects of PPAT CM from patients with PCa and BPH on the adhesion, proliferation, migration and metalloproteinase release of LNCaP and PC3 cells.

The present study provides the first evidence that periprostatic adipose tissue produces and releases pro-MMP-9, and that PPAT CM from patients with PCa have a tendency to present higher activity of pro-MMP-9 than PPAT CM from patients with BPH. In addition, the densitometric analysis of zymograms demonstrates that TPPAT CM are more effective than BPPAT CM in inducing release of pro-MMP-9 activity in LNCaP. This behavior is probably due to the different composition of both types of $\mathrm{CM}$, which may be dependent on prostate microenvironment (tumor or benign). Androgen independent PC3 cells do not show such differences and thus, PPAT CM may contain factors that stimulate pro-MMP-9 release by PCa cells representing the first stage of the disease, such as LNCaP. Other authors have found higher expression of all MMPs and TIMPs in prostate carcinomas compared to benign pathologies [26] and stimulation of PPAT with PC3 CM has been shown to induce an increase in MMP9 activity by tissue explants [9]. Furthermore, there is evidence that induction of proMMP-9 in PCa cells and reduction of TIMPs in stromal cells does not require cell-cell contact and is mediated by soluble factor(s) present in CM of the effector cells [27].

We also found that the number of LNCaP cells attached to the components of TPPAT CM is significantly lower than the number of cells attached to the components of BPPAT CM. These data are suggestive of the capacity of androgen dependent cells, corresponding to early stages in prostate cancer, to invade tumor microenvironment. PC3 cells appear to be more adhesive than LNCaP to components of PPAT CM, regardless of the source (tumor or benign) of the $\mathrm{CM}$, suggesting that androgen independent cells could be using components of adipose tissue for further colonization. Also in the case of PC3, versican or hyaluronan appear to be necessary for cell attachment, as revealed by the results obtained after pre treating BPPAT CM with ChABC.

No effect of PPAT CM could be observed on proliferation and migration of LNCaP and PC3 cells. Probably, cell-cell contact or higher concentrations of soluble factors are necessary to observe any changes in both these processes.

Preliminary data show that TPPAT CM present higher levels of IL- 6 than BPPAT CM. It is well known that IL-6 and MMP-9 have pro-angiogenic and pro-metastatic properties, and thus both these factors could be associated with negative prognosis in PCa. This hypothesis needs to be further tested with the analysis of a larger number of samples and a patient follow up to evaluate progression of the disease.

In conclusion, the findings presented in this study provide new insight on the crosstalk between epithelial prostate tumor cells and periprostatic adipose tissue, which could be part of the mechanisms underlying tumor initiation and progression. A broader understanding of this interaction may contribute to the development of new therapies involving microenvironment targeting.

Additional studies, involving a larger number of patients, are presently being conducted in our laboratory in order to correlate the amount and composition of adipose tissue with the factors produced and/or released by TPPAT and BPPAT. We believe that both studying the adipoparacrinology [28] and "mapping" of the fat will provide a step forward in the understanding of prostate diseases.

\section{Conflict of Interest}

The authors have no potential conflicts of interest in the present work. 


\begin{tabular}{rl|l} 
Cellular Physiology & $\begin{array}{l}\text { Cell Physiol Biochem 2012;30:113-122 } \\
\text { and Biochemistry }\end{array}$ & $\begin{array}{l}\text { DOI:10.1159/000339051 } 2012 \text { S. Karger AG, Basel } \\
\text { Published online: June 13, 2012 }\end{array}$ \\
\cline { 2 - 3 } Sacca/Creydt/Choi et al.: Periprostatic Adipose Tissue and Prostate Cancer
\end{tabular}

\section{Acknowledgements}

The authors thank the team of the Urology Department, Hospital de Clínicas “José de San Martín" for collecting adipose tissue and Dr. Lucrecia Piñeiro for the careful revision of this manuscript. This study was supported by grants to Juan C Calvo from CONICET (PIP5402) and ANPCYT (PICT35084/05) and a donation from Fundación Honorio Bigand.

\section{References}

1 Hong H, Koch MO, Foster RS, Bihrle R, Gardner TA, Fyffe J, Ulbright TM, Eble JN, Cheng L: Anatomic distribution of periprostatic adipose tissue: A mapping study of 100 radical prostatectomy specimens. Cancer 2003;97:639-1643.

2 Kiyoshima K, Yokomizo A, Yoshida T, Tomita K, Yonemasu H, Nakamura M, Oda Y, Naito S, Hasegawa Y: Anatomical features of periprostatic tissue and its surroundings: A histological analysis of 79 radical retropubic prostatectomy specimens. Jpn J Clin Oncol 2004;34:463-468.

3 van Roermund JG, Bol GH, Witjes JA, Ruud Bosch JL, Kiemeney LA, Van VM: Periprostatic fat measured on computed tomography as a marker for prostate cancer aggressiveness. World J Urol 2010;28:699-704.

4 Bihindi B, Trottier G, Elharram M, Fernandes KA, Lockwood G, Toi A, Hersey KM, Finelli A, Evans A, van der Kwast TH, Fleshner NE: Measurement of peri-prostatic fat thickness using transrectal ultrasonography (TRUS): A new risk factor for prostate cancer. BJU Int 2012; DOI: 10.1111/j.1464-410X.2012.10957.x

5 Alvarez-Llamas G, Szalowska E, de Vries MP, Weening D, Landman K, Hoek A, Wolffenbuttel BH, Roelofsen H, Vonk RJ: Characterization of the human visceral adipose tissue secretome. Mol Cell Proteomics 2007;6:589-600.

6 Baillargeon J, Rose DP: Obesity, adipokines, and prostate cancer (review). Int J Oncol 2006;28:737-745.

7 Mistry T, Digby JE, Desai KM, Randeva HS: Leptin and adiponectin interact in the regulation of prostate cancer cell growth via modulation of p53 and bcl-2 expression. BJU Int 2008;101:1317-1322.

8 Finley DS, Calvert VS, Inokuchi J, Lau A, Narula N, Petricoin EF, Zaldivar F, Santos R, Tyson DR, Ornstein DK: Periprostatic adipose tissue as a modulator of prostate cancer aggressiveness. J Urol 2009;182:1621-1627.

9 Ribeiro RJT, Monteiro CPD, Cunha VFPM, Azevedo ASM, Oliveira MJ, Monteiro R, Fraga AM, Principe P, Lobato C, Lobo F, Morais A, Silva V, Sanches-Magalhaes J, Oliveira J, Guimaraes JT, Lopes CMS, Medeiros RM: Tumor cell-educated periprostatic adipose tissue acquires an aggressive cancer-promoting secretory profile. Cell Physiol Biochem 2012;29:233-240.

10 Niu YN, Xia SJ: Stroma-epithelium crosstalk in prostate cancer. Asian J Androl 2009;11:28-35.

11 Karlou M, Tzelepi V, Efstathiou E: Therapeutic targeting of the prostate cancer microenvironment. Nat Rev Urol 2010;7:494-509.

12 Chakraborti S, Mandal M, Das S, Mandal A, Chakraborti T: Regulation of matrix metalloproteinases: An overview. Mol Cell Biochem 2003;253:269-285.

13 Butler GS, Overall CM: Updated biological roles for matrix metalloproteinases and new "Intracellular" Substrates revealed by degradomics. Biochemistry 2009;48:10830-10845.

14 Hadler-Olsen E, Fadnes B, Sylte I, Uhlin-Hansen L, Winberg JO: Regulation of matrix metalloproteinase activity in health and disease 1. FEBS J 2011;278:28-45.

15 Cao J, Chiarelli C, Richman O, Zarrabi K, Kozarekar P, Zucker S: Membrane type 1 matrix metalloproteinase induces epithelial-to-mesenchymal transition in prostate cancer. J Biol Chem 2008;283:6232-6240.

16 Dozmorov MG, Hurst RE, Culkin DJ, Kropp BP, Frank MB, Osban J, Penning TM, Lin HK: Unique patterns of molecular profiling between human prostate cancer LNCap and PC-3 cells. Prostate 2009;69:1077-1090.

17 Horoszewicz JS, Leong SS, Chu TM, Wajsman ZL, Friedman M, Papsidero L, Kim U, Chai LS, Kakati S, Arya SK, Sandberg AA: The LNCaP cell line: a new model for studies on human prostatic carcinoma. Prog Clin Biol Res 1980;37:115-132.

18 Horvath LG, Lelliott JE, Kench JG, Lee CS, Williams ED, Saunders DN, Grygiel JJ, Sutherland RL, Henshall SM: Secreted frizzled-related protein 4 inhibits proliferation and metastatic potential in prostate cancer. Prostate 2007;67:1081-1090. 


\section{Cellular Physiology Cell Physiol Biochem 2012;30:113-122 \\ \begin{tabular}{ll|l} 
and BiOChemistry & $\begin{array}{l}\text { DOI:10.1159/000339051 } \\
\text { Published online: June 13, } 2012\end{array}$ & $\begin{array}{l}\text { C 2012 S. Karger AG, Basel } \\
\text { www.karger.com/cpb }\end{array}$ \\
\cline { 2 - 3 } Sacca/Creydt/Choi et al: Periprostatic Adipose Tissue and Prostate Cancer
\end{tabular}}

19 Killilea AN, Downing KH, Killilea DW: Zinc deficiency reduces paclitaxel efficacy in LNCap prostate cancer cells. Cancer Lett 2007;258:70-79.

20 Sarveswaran S, Liroff J, Zhou Z, Nikitin AY, Ghosh J: Selenite triggers rapid transcriptional activation of p53, and p53-mediated apoptosis in prostate cancer cells: Implication for the treatment of early-stage prostate cancer. Int J Oncol 2010;36:1419-1428.

21 Retta SF, Ternullo M, Tarone G: Adhesion to matrix proteins; in Dejana E, Corada M (eds): Adhesion protein protocols. Totowa, NJ, Humana Press INC, 1999, pp 125-130.

22 Sakko AJ, Ricciardelli C, Mayne K, Suwiwat S, LeBaron RG, Marshall VR, Tilley WD, Horsfall DJ: Modulation of prostate cancer cell attachment to matrix by versican. Cancer Res 2003;63:4786-4791.

23 Pucci-Minafra I, Minafra S, La RG, Barranca M, Fontana S, Alaimo G, Okada Y: Zymographic analysis of circulating and tissue forms of colon carcinoma gelatinase a (MMP-2) and b (MMP-9) separated by monoand two-dimensional electrophoresis. Matrix Biol 2001;20:419-427.

24 Olson MW, Bernardo MM, Pietila M, Gervasi DC, Toth M, Kotra LP, Massova I, Mobashery S, Fridman R: Characterization of the monomeric and dimeric forms of latent and active matrix metalloproteinase-9. Differential rates for activation by stromelysin 1. J Biol Chem 2000;275:2661-2668.

25 Chung LW, Baseman A, Assikis V, Zhau HE: Molecular insights into prostate cancer progression: The missing link of tumor microenvironment. J Urol 2005;173:10-20.

26 Escaff S, Fernandez JM, Gonzalez LO, Suarez A, Gonzalez-Reyes S, Gonzalez JM, Vizoso FJ: Study of matrix metalloproteinases and their inhibitors in prostate cancer. Br J Cancer 2010;102:922-929.

27 Dong Z, Nemeth JA, Cher ML, Palmer KC, Bright RC, Fridman R: Differential regulation of matrix metalloproteinase-9, tissue inhibitor of metalloproteinase-1 (TIMP-1) and TIMP-2 expression in cocultures of prostate cancer and stromal cells 10. Int J Cancer 2001;93:507-515.

28 Chaldakov GN, Beltowsky J, Ghenev PI, Fiore M, Panayotov P, Rancic G, Aloe L: Adipoparacrinology-vascular periadventitial adipose tissue (tunica adiposa) as an example. Cell Biol Int 2012;36:327-330. 